\title{
An Accent-Plus Lesson for an English Phonetics Class: Integrating Indian English into Contrastive Analysis
}

\author{
James H. Yang \\ Department of Applied Foreign Languages, National Yunlin University of Science and Technology, Taiwan \\ Email: jamesyang1118@gmail.com
}

\begin{abstract}
Despite the diverse forms of English used and spoken around the world, most English learners tend to regard English as a homogeneous language, mistakenly believing that its linguistic variation is an error or a defect, regardless of the context where it operates for international and intranational communication. In response to Kachru and Smith's (2008) proposal of a paradigm shift towards pluralistic models of English and Larsen-Freeman's (2007) deconstructive perspective of the acquisition/participation dichotomy, this paper devised a specific accent-plus lesson on Indian English for English phonetics teachers to enhance English learners' ethnosensitivity towards diverse ways of speaking English in different countries.
\end{abstract}

Index Terms_English accents, phonology, Indian English, World Englishes

\section{INTRODUCTION}

Expanding-circle English (ECE) speakers ${ }^{1}$ who only acquire Standard English (SE) for the academic purposes are usually unaware that distinct varieties of English are spoken with unique accents among different English speakers due to the worldwide spread of English as the international lingua franca (Filppula et al., 2009; Gimenez, 2001; Jenkins, 2007; Kirkpatrick, 2007; Wajnryb, 2008; Wolf, 2008). Therefore, English learners need to be informed that English is not merely spoken by native English (NE) speakers but also by nonnative English (NNE) speakers in various settings for different purposes (Widdowson, 1994). As Canagarajah puts it (2006, p. 229):

The changing pedagogical priorities suggest that we have to move away from a reliance on discrete-item tests on formal grammatical competence and develop instruments that are sensitive to performance and pragmatics. In effect, assessment would focus on strategies of negotiation, situated performance, communicative repertoire, and language awareness.

Given the realities of English used in different countries and international communication, limiting one's teaching of the English language to SE is inadequate and misleading. It is necessary to dispel the elitist view that General American English (GAE) and Standard British English (SBE, i.e., Received Pronunciation, RP) are the only ones worthy of study in terms of global interaction and intercultural exchange. In this respect, Kirkpatrick (2007, pp. 196-7) remarked, "Well-trained, multilingual and culturally sensitive and sophisticated teachers can best teach today's learners of English."

Unfortunately, a survey of American MA programs in TESOL indicates that very few courses were designed to train students in the use of different varieties of English. Milroy and Milroy (1999, p. 94) commented that the projection of socio-cultural identity appears to be more important than the acceptance of SE. For instance, in the use of English for international communication, Inner-Circle speakers usually do not imitate SE, although they might accommodate their speeches towards one another for effective mutual understanding. Wassink (1999) also noticed that most young Jamaican English speakers have positive feelings for their indigenous varieties of English. The claim made by Tony Tan, the former Education Minister of Singapore, also reveals the importance of local identities over SE (cited in Pennycook, 1994, p. 222),

We do not wish to be a pseudo-Western society. While we need to learn and use English to master technology and enhance our competitive edge in the international business community, we should not let the use of English override the importance of keeping our links to our cultural roots strong and healthy (The Sunday Times, March, $10^{\text {th }} 1991$ ).

Examples such as these indicate that different English speakers' positive attitudes towards their distinct language usages and accents are becoming increasingly apparent.

Nevertheless, the value system represented in Western-produced English-learning textbooks tends to be rather ethnocentric, giving little or no consideration to different national varieties of English (Gill, 2002; Nihalani et at., 2004).

\footnotetext{
1 According to Kachru (1985), the Expanding Circle refers to the countries where English is mainly acquired to interact with foreigners, while the national language is usually the mother tongue spoken and used by the majority to interact with each other domestically, as in Taiwan and Turkey. By contrast, the Inner circle denotes such countries as Australia and Canada where English is generally spoken as the native language, whereas the Outer Circle includes the countries where English operates as an associate language alongside national languages, as in India and Singapore.
} 
In addition to national standards, very few textbooks address English regiolects. Standard English is usually taught and used only in school (or to be more accurate, only in English classes) and have limited functions in real-world communication. Although students learn SE in school, they tend to regard such formal communication patterns as "textbook" English and rarely use them in their daily interactions. For instance, Americans learn GAE in school, but on a daily basis they tend to use local English dialects, such as African-American Vernacular English, White American English Vernaculars, and other English ethnic dialects (Rickford, 1999).

Those who insist on using standard textbook English (if indeed that were possible) are likely to be perceived as wanting to maintain a certain social distance, and might even be regarded by their colleagues as arrogant individuals who want to show off their language skills. Ironically, the inappropriate use of SE in causal social interactions with associates often results in communication breakdowns. Crosling and Ward (2002) reported that the ability to make formal presentations is by itself inadequate preparation for the workplace because most oral communication in international companies is informal in nature. They found that colleagues in the same department mostly use informal English for work-related discussions. In another study, Gill (2002) noted that standard forms of English are only used to give company presentations.

Accordingly, ECE learners need to be aware that English speakers, native and nonnative alike, all speak English with accents to some extent in interactions with one another. With the emergence of 'New Englishes,' the question of whether global English will be British English or American English has been dated (Graddol, 1997). The primacy of NE speakers' standards and conventions for international communication are ideologically undesirable and practically untenable (Kachru \& Smith, 2008) given the facts that distinct varieties of English have evolved with their own standards (Trudgill, 2004), nonstandard/nonnative speakers have largely outnumbered native speakers (Crystal, 2003), and most significantly, the interaction among nonstandard/nonnative speakers has rapidly increased worldwide (Mattock, 2003). Commenting on the current diversity of English, Crystal (2003, p. 130) stated, "No one now can claim sole ownership of English, emphasizing that this attitude is probably the best way of defining a genuinely global language." Therefore, teachers need to sensitize their students to distinct varieties of English used in different countries.

\section{PluRAlistic Models OF ENGLish}

The above reflection on the actual use of English in the world does not mean to dichotomize the social dimension of language use with the cognitive view of language acquisition. Nor does it exclude the pedagogical norm of SE. Rather, it illustrates the need for a social and contextual orientation to the acquisition of English as a lingua franca for international communication, because the mainstream of English acquisition has long been constructed on such frameworks as interlanguage, performance analysis, and language transfer. From Larsen-Freeman's (2007) chaos/complexity perspective, the acquisition/participation dichotomy can be deconstructed to regard language learning as the dynamic process that emphasizes both linguistic and social competences on which language learners might draw as their identities and strategies in interaction and negotiation for different purposes.

Awareness of distinct varieties of English does not reject SE. One still needs to acquire and use SE in a formal context. It is not SE but its ideology that needs to be redressed in light of the worldwide spread of English (Bhatt, 2002; Brutt-Griffler, 2002; Jenkins, 2007). From Kachru's (1985) concept of World Englishes, English teachers need to raise English learners' awareness that SE might be defined differently in different nations and that one might learn SE but present different proficiencies and adapt it with local varieties of English to various social contexts. To help ECE learners improve their English proficiency, a teacher can contrast SE with other varieties of English in terms of their grammar, accents, and pragmatics. Unlike error analysis, however, this contrastive analysis can not only stren gthen their language skills but also acknowledge other English varieties as diverse ethnic ways of speaking.

Indeed, variation is not merely the spice of life but also the essence of life. Canagarajah (2006) stressed the awareness of World Englishes because it enables a person to "shuttle between diverse communities in the postmodern world" (p. 237). As Kosslyn (2006, p. 555) remarked,

Diversity is not a luxury, but rather is essential in many walks of life. Think about why a carpenter has many different devices in his toolbox. It's impossible to know in advance what challenges the environment will produce, and what abilities will need to be marshaled...to help us negotiate future challenges.

It is time to highlight ethnosensitive, receptive competence in the classroom, in addition to linguistic competence. Hearers tend to make assumptions about SE and then use them to pass negative judgments on 'odd' accents, 'weird' expressions, and 'strange' discourse practices, thereby discriminating against speakers who use different varieties of English. Influenced by the SE ideology, NNE speakers also feel incompetent if they fail to speak and use SE (Lippi-Green, 1997). Due to the existence of distinct varieties of English that have developed in different nations as a result of the natural evolution of language, a tolerant and open-minded attitude towards diverse ways of speaking English for interethnic communication should be encouraged in the classroom.

Pedagogical approaches can do much to resolve these issues. Drawing on Kachru and Smith's (2008) pedagogical framework of World Englishes and Larsen-Freeman's (2007) chaos/complexity perspective of the dynamic language acquisition process, this paper proposes an accent-plus lesson plan for English phonetics teachers to help ECE learners become aware of distinct English accents spoken in different nations. 


\section{An ACCENT-Plus Lesson Plan}

To begin with, an English phonetics teacher can analyze the sound differences between two pedagogical standards of the English language: British English (BE) and General American English (GAE). This paper demonstrates an online video to discuss $\mathrm{BE}^{2}$, which was filmed by Ben, a BE speaker, in his application for a job as an island caretaker to explore the Islands of the Great Barrier Reef in Queensland Australia. His well-designed video appears radiantly outstanding among a shortlist of 50 applicants from 22 countries; after the interview, he was finally offered the job from the final 16 applicants. The video was transcribed below:

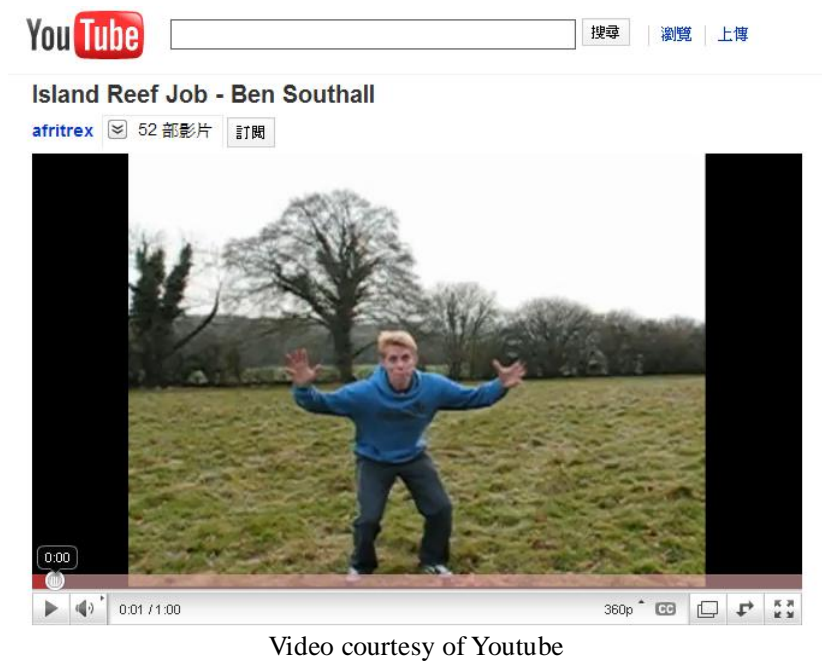

Hi, I'm Ben, or otherwise known as the adventurous, crazy, energetic, one, and there's only 55 seconds left to tell you why! Ahhh! I love discovering new places. Last year I drove all around Africa. I cross deserts, climb mountains, run marathons, bungee jump, mountain bike, scuba dive, and snorkel everywhere, because...I'm practically a fish myself! As for trying new things, how about riding an ostrich? What can I say; animals love me, and I love them too, especially if they're rare; well, ok, maybe not that rare. I'm a great communicator, I love meeting people, and immersing myself in other cultures. I've written newspaper and magazine articles, given TV and radio interviews, and kept a journal and video blog on my website to share my experiences with others, and I'd love to do the same for you. We can learn about the 100 Miles of Magic Great Barrier Reef together, and all that Queensland has to offer. I'm an experienced events manager, charity fundraiser, and tour guide. I have a bachelor of science degree and a keen interest in photography. So I'm your man. If it's the best job in the world, then I'm off to the best place in the world.

After playing the video, the teacher can ask students if they notice any linguistic differences between GAE and the way Ben speaks English in the video. For instance, Ben did not pronounce the syllable-final retroflex, as illustrated in such words as there, year and share. Intriguingly, he said /ju/ for the nuclei in such words as new and newspaper, while GAE only utters the vowel /u/. In addition, he changed the vowel /æ/ into /a/ in words, including Africa, magazine, magic, and bachelor. Furthermore, he said /o/ for the vowel / $\alpha /$, as shown in on, job, and ostrich. He also underwent the diphthong shifts including the change of /aI/ into / $\Lambda \mathrm{I} /$ and the change of /ov/ into /əU/. These sound changes occur regularly, not sporadically. Below is the summary of the prominent BE features different from GAE (adapted from Upton, 2008):

- Non-rhotic accent: the retroflex vowel /̌̌/ changes into /3/, as in word /w3d/.

- Insertion of /j/ between a coronal and /u/, as in such words as news, students, tube, nude, and dew.

- Low front vowel shift: /æ/ changes into the back vowel /a/ (or /a/ or /e/), as in bath /ba $\theta /$.

- Low back vowel shift: /a/ changes into its round counterpart /o/, as in hot /hot/.

- Diphthong shifts: /aI/ becomes / $\Lambda \mathrm{I}$, and /ou/ becomes /əu/.

By and large, different varieties of English share a similar consonant inventory, but differ considerably in their pronunciation of vowels. The following table displays how $\mathrm{GAE}^{3}$ differs vocalically from Standard British English (i.e., Received Pronunciation, RP). ${ }^{4}$ The teacher can use it to raise students' awareness of how the two standard varieties of English contrast phonetically with each other.

\footnotetext{
2 This BE video appears here: http://www.youtube.com/watch?v=PnosVJfDrpY. The mirror site is available here: http://teacher.yuntech.edu.tw/yanght/research/videos/BE-ben.wmv.

3 This study employs Heinle's Newbury House Dictionary of American English for sound comparison; it is available online: http://nhd.heinle.com/Home.aspx.

${ }^{4}$ Upton's (2008) description of RP is used as a point of reference in this study.
} 
TABLE 1.

THE VOWELS OF GAE AND RP ACCORDING TO WELL'S (1982) LEXICAL SET

\begin{tabular}{|c|c|c|}
\hline Word & $\mathrm{RP}$ & GAE \\
\hline Fleece & i: & $\mathrm{i}$ \\
\hline Kit & $\mathrm{I}$ & I \\
\hline Face & eI & eI \\
\hline Dress & $\varepsilon$ & $\varepsilon$ \\
\hline Trap & $\mathrm{a}$ & $æ$ \\
\hline Bath & $\mathrm{a}: \sim \mathrm{a}$ & $æ$ \\
\hline Strut & $\Lambda$ & $\Lambda$ \\
\hline Palm & $\mathrm{a}:$ & $a$ \\
\hline Lot & $\mathrm{p}$ & $\mathrm{a}$ \\
\hline Goose & $\mathrm{u}:$ & $\mathrm{u}$ \\
\hline Foot & $U$ & $U$ \\
\hline Goat & $\partial U$ & $\mathrm{OU}$ \\
\hline Cloth & $\mathrm{p}$ & 0 \\
\hline Thought & o: & 0 \\
\hline Price & $\Lambda \mathrm{I}$ & aI \\
\hline Choice & गI & OI \\
\hline Mouth & au & $\mathrm{au}$ \\
\hline Near & Iə & Ir \\
\hline Square & $\varepsilon:$ & $\varepsilon r$ \\
\hline Nurse & ว: & $3^{n}$ \\
\hline Start & $\mathrm{a}:$ & ar \\
\hline North & o: & or \\
\hline Force & $0:$ & or \\
\hline Cure & Uว ว: & jur \\
\hline Tuesday & ju & $\mathrm{u}$ \\
\hline happY & $\mathrm{i}$ & $\mathrm{i}$ \\
\hline lettER & $\partial$ & $\mathrm{r}$ \\
\hline commA & $\partial$ & $\partial$ \\
\hline
\end{tabular}

Next, this paper demonstrates an accent-plus lesson plan that analyzes Indian English (IE) as an example to sensitize students towards different ways of speaking English. To this end, this paper utilizes a TV commercial available online to compare with IE with GAE. This video is a popular TV commercial released in India to promote Pepsi. ${ }^{5}$ Its transcription is shown below:

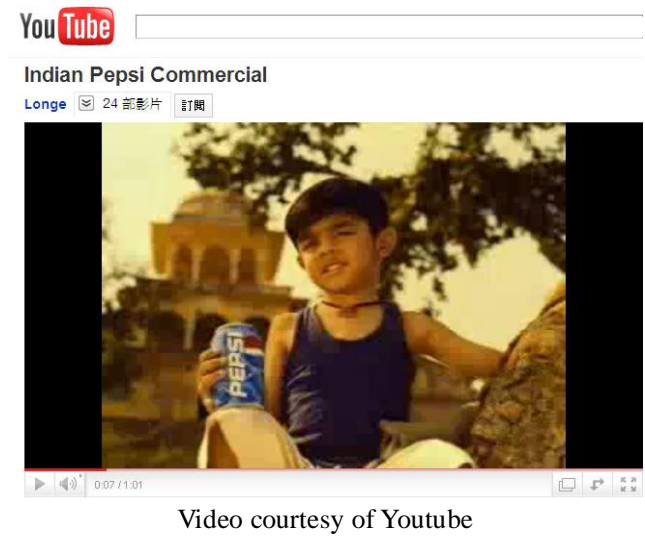

As far as I can remember, I've always lived with elephants. Then, one day, I discovered I had power over them. So I decided to plan them to do something special_ "The Elephant Tower." My elephant towers became bigger and bigger. I was famous all over India. But I was wrong about those animals. Elephants were not a good idea. I think I'm back.

After playing the video, the teacher can ask the students whether they notice any words that are pronounced differently than they are pronounced in GAE/RP. The teacher then helps the students identify and analyze such words by playing the video one sentence at a time. The teacher proceeds to explain the sound features of IE observed in the video. First, the narrator's spoken English is characterized by an r-less accent, reflecting a typical BE accent. Specifically, the syllable-final r-sound is not deleted but enunciated as schwa, as in far, remember, power, over, tower, bigger, and were. This finding is unsurprising, because India had long been a British colony before becoming a republic in 1947. In fact, beginning in the 16th century, Portugal, the Netherlands, and France also established trading posts in India.

Like RP, educated Indian English (IE) has a non-rhotic accent, but the word-final /r/ is usually pronounced when

\footnotetext{
${ }^{5}$ This video appears on Youtube: http://www.youtube.com/watch? $\mathrm{v}=\mathrm{dSCr}-\mathrm{Ul6O} 8 \mathrm{U} \& \mathrm{p}=164 \mathrm{~B} 8 \mathrm{CCA} 542 \mathrm{FAFD} 7 \& \mathrm{playnext}=1 \&$ index $=56$. Its mirror site is available here: http://teacher.yuntech.edu.tw/yanght/research/videos/IE.wmv.
} 
followed by a word beginning with a vowel, as in interaction, the car is coming, and the player insisted on his principle (Sailaja, 2009, p. 19-20). This sound feature, however, does not appear in this video, as in such possible phrases as power over them and all over India. Although cultivated IE is non-rhotic, general IE is rhotic (Gargesh, 2008, p. 237; Sailaja, 2009, p. 20).

Another noticeable RP phonological feature is the vowel shift from /æ/ to / $/$ /, as in such words as had, plan, animals, and back. The lax epsilon / $/$ / in turn becomes its tense counterpart /e/, as illustrated in words like remember, elephant, and them. The most distinctive aspect of the accent in the IE commercial is the lack of aspiration of voiceless stops, as in power and tower. The common IE features observed in the video are summarized as follows (Gargesh, 2008):

- Rhotic accent (general IE), non-rhotic accent (cultivated IE)

- Vowel shift from $/ æ /$ to $/ \varepsilon /$, as in plan.

- Vowel shift from /E/ to /e/, as in elephant.

- Unaspiration of voiceless stops, as in power.

Additionally, IE also features the insertion of $/ \mathrm{j} /$ between a coronal and $/ \mathrm{u} /$, as in such words as student and tube (Gargesh, 2008; Nihalani et al., 2004). However, this feature is not observable in the commercial. Moreover, other frequent distinctive IE features do not occur in the video, including the shift of interdental fricatives to dental stops (e.g. with, then, something, those, and think), the realization of the stops $/ \mathrm{t} /$ and $/ \mathrm{d} /$ as retroflexes, and the peculiar exchange between /v/ and /w/ (Nihalani et al., 2004).

Additionally, the narrator's intonation sounds fairly different from the Inner-Circle varieties of English under examination. For instance, the IE speaker tends to give a falling tone (231) to the last word of the non-final sentence, as indicated below:

(1) As far as I can remember (a falling tone), I've always lived with elephants.

(2) Then, one day (a falling tone), I discovered I had power over them.

By contrast, native English speakers tend to use a slightly falling tone (232), a plain tone (22), or a curve tone (2312) for emphasis (Clark, 2009; Hughes, 2006).

After the sound analysis of the video, the teacher can give the students an assignment to analyze the way other IE speakers speak English. The teacher can provide the following table for the students to examine whether some words undergo the given sound features:

TABLE 2.

COMMON IE SOUND FEATURES

\begin{tabular}{|l|l|l|}
\hline Sound changes & Examples & $\begin{array}{l}\text { Exceptions } \\
\text { The words that don't undergo the sound features }\end{array}$ \\
\hline Rhotic or non-rhotic accent & & \\
\hline Insertion of /j/ between a coronal and /u/ & & \\
\hline$/ æ / \rightarrow / \varepsilon /($ or $/ \mathrm{a} /$ or $/ \mathrm{a} /$; which one do you perceive?) & & \\
\hline$/ \varepsilon / \rightarrow / \mathrm{e} /$ & & \\
\hline Unaspiration of voiceless stops & & \\
\hline Interdental fricatives to dental stops & & \\
\hline Realization of the stops /t/ and /d/ as retroflexes & & \\
\hline Exchange between /v/ and /w/ & & \\
\hline Other features that you notice & & \\
\hline
\end{tabular}

For the assignment, the teacher can recommend the students ted.com, where they can analyze an IE speaker like Pranav Mistry.

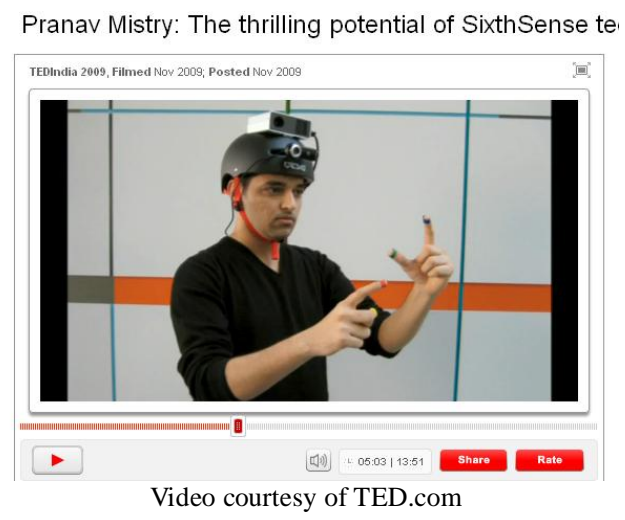

\footnotetext{
${ }^{6}$ Pranav Mistry, an MIT PhD candidate, talks about the thrilling potential of SixthSense technology, which helps the physical world interact with the world of data. His talk appears here: http://www.ted.com/talks/lang/en/pranav_mistry_the_thrilling_potential_of_sixthsense_technology.html. The mirror site is available here: http://teacher.yuntech.edu.tw/yanght/research/videos/IE-mistry.wmv.
} 
The teacher can also encourage them to analyze songs sung by Indians. By integrating accent-plus lesson plans like this into an English phonetics course, the teacher can not only enhance students' awareness of the sound contrast between SE and IE, but she can also expand their listening comprehension repertoire for effective communication with IE speakers (Scales et al., 2006).

\section{ANALYZING ENGLISH TV COMMERCIALS}

This paper has presented a TV commercial to demonstrate how IE differs phonetically from SE. Accordingly, a teacher can make use of TV commercials to discuss distinct ways of speaking English in different countries. According to Gill' (2002) research on TV commercials in Malaysia, local basilectal (broad) and mesolectal (general) varieties of English are often deployed to capture listeners' attention, because they are the varieties most Malaysians speak in daily life. This report indicates that advertisers usually employ popular colloquial varieties of English to engender a sense of friendliness and also to remind customers that their products are designed for them and for everyday use. By contrast, acrolectal (educated or cultivated) English is often utilized to present product features. Gill (2002, p. 97) observed that at the summary level, where the product is announced, advertisers tend to use acrolectal English; they prefer Standard Malaysian English for making statements about their products and services. Examples such as these reveal that business people wishing to promote their products in other nations need to understand the associations of the local English sociolects.

One approach to finding online videos suitable for the teaching of English accents is to use the search engine on the homepage of YouTube, but this can be difficult and time consuming due to the vast number of videos available on this website. One way of making the selection process more efficient is to limit the search to TV commercials available online. TV commercials are not only interesting and brief, but also demonstrate different ways of speaking, thus providing authentic data for comparing SE with other varieties of English. The following two online databases of international TV commercials are particularly useful:

http://www.adforum.com

http://www.publivores.com

The website TED.com is also helpful because it includes different speakers talking about a wide range of topics, and also provides subtitles - especially helpful for increasing intelligibility.

Additionally, the teacher can also help students analyze how the accent differs from SE and their ways of speaking. Because of growing international interaction among NNE speakers, one needs to be aware of distinct English accents. A useful website for preparing for this activity is the speech accent archive created by George Mason University: http://accent.gmu.edu/index.php. Moreover, students can listen to an online radio news broadcast spoken in English from a different nation. Worldwide Radio (http://www.live-radio.net/worldwide.shtml) provides links to thousands of radio stations worldwide. The instructor can ask students how well they can understand a piece of news and then examine the difficulty the students might encounter. For instance, general (or mesolectal) Indian English frequently misplace the stress on the second syllable of the poly-syllabic word such as ci'ty, fami'ly and cha'racter (Bansal, 1969). Moreover, Indian English speakers tend to use the dental stop / $t$ / in substitution for the syllable-final interdental fricative, as in such words as with, earth, mouth, and death (Sailaja, 2009). Through listening practices and sound analyses, students can familiarize themselves with IE accents (see Jenkins' books published in 2000, 2003 and 2007 for more details on the implications of World Englishes for international communication). Such familiarity, together with contrastive accent analysis, can help them interact effectively with IE speakers.

\section{CONCLUSION}

This paper has proposed an accent-plus lesson plan for English phonetics teachers to teach ECE learners IE accent in contrast to SE as an example of raising their awareness of distinct English accents spoken in different nations. Based on Kachru and Smith's (2008) pluralistic model of World Englishes and Larsen-Freeman's (2007) deconstructive perspective of the acquisition/participation dichotomy, this lesson plan has incorporated three essential components into the course: 1) developing an awareness of IE accents via linguistic exposure and contrastive analysis; 2) developing an awareness of English usage in a TV commercial; and 3) developing familiarity with IE accents. Because English has spread so pervasively that it no longer belongs exclusively to Americans and Britons, it is crucial to raise awareness of the status and functions of various forms of English used worldwide today (Kachru \& Smith, 2008). As Rickford (1999, p. 151) remarks,

English is not a single entity, but, like any other living language, is something that varies considerably depending on one's regional background, social class and network, ethnicity, gender, age, and style, to name only the most salient dimensions. Understanding and recognizing such variation is essential for language arts and second and foreign language teachers.

With the use of English as a lingua franca in the world, English teachers need to help ECE learners understand how English is actually used in the world. They should not merely stress language skills but also discuss different varieties of English in a global context. The accent-plus lesson plan presented above has emphasized that ECE learners need to understand IE accents and develop receptive competence of other English accents as well. Such receptive competence 
can help students make an educated guess at the ethnic origins of their future interlocutors, enabling them to employ appropriate discourse practices (McKay \& Bokhorst-Heng, 2008; Smith, 1992; Wajnryb, 2008).

By familiarizing students with different English accents in the concept of World Englishes, English teachers can well prepare them to live with diversity and to cooperate with others in a global society - two of the core capacities that Bok (2006), Winner of the 2008 Frederic W. Ness Book Award for his thoughtful critique of higher education, urged teachers to integrate into their teaching materials. Canagarajah (2006, p. 238) also commented:

People use speech accommodation to inch toward each other as they modify their differences. They use interpersonal strategies such as repair, rephrasing, clarification, gestures, topic change, and other consensus-oriented and mutually supportive practices. Attitudinal resources can help. One needs patience, tolerance, and humility to negotiate differences. A lack of these attitudes might prevent even those with the same language from communicating with each other.

It is hoped that this accent-plus lesson plan will inspire English phonetics teachers and, by extension, English language educators to design their own accent awareness lessons for their students in preparation for actual English use in international interaction.

\section{REFERENCES}

[1] Bansal, R. K. (1969). The intelligibility of Indian English: Measurements of the intelligibility of connected speech, and sentence and word material, presented to listeners of different nationalities. Hyderabad, India: Central Institute of English.

[2] Bhatt, R. M. (2002). Experts, dialects, and discourse. International Journal of Applied Linguistics, 12(1), 74-109.

[3] Bok, D. (2006). Our underachieving colleges: A candid look at how much students learn and why they should be learning more. Princeton, NJ: Princeton University Press.

[4] Brutt-Griffler, J. (2002). World English: A study of its development. Clevedon: Multicultural Matters Ltd.

[5] Canagarajah, S. (2006). Changing communicative needs, revised assessment objectives: Testing English as an international language. Language Assessment Quarterly, 3(3), 229-242.

[6] Clark, B., \& Wharton, T. (2009). Understanding English intonation. Paper presented at the ICLCE3 (3rd International Conference on the Linguistics of Contemporary English).

[7] Crosling, G., \& Ward, I. (2002). Oral communication: the workplace need and uses of business graduate employees. English for Specific Purposes, 21, 41-57.

[8] Crystal, D. (2003). English as a global language (2nd edition ed.). Cambridge: Cambridge University Press.

[9] Filppula, M., Klemola, J., \& Heli, P. (Eds.). (2009). Vernacular universals and language contacts: Evidence from varieties of English and beyond. New York: Routledge.

[10] Gargesh, R. (2008). Indian English: Phonology. In R. Mesthrie (Ed.), Varieties of English: Africa, South and Southeast Asia (pp. 231-243). New York: Mouton de Gruyter.

[11] Gill, S. K. (2002). English language challenges for Malaysia: International communication. Universiti Putra: Malaysia Press.

[12] Gimenez, J. C. (2001). Ethnographic observations in cross-cultural business negotiations between nonnative speakers of English: An exploratory study. English for Specific Purposes, 20, 169-193.

[13] Graddol, D. (1997). The future of English? London: British Council.

[14] Hughes, R. (2006). Spoken English, TESOL, and applied linguistics: challenges for theory and practice. New York: Palgrave Macmillan.

[15] Jenkins, J. (2000). The phonology of English as an international language: New models, new norms, new goal. Oxford: Oxford University Press.

[16] Jenkins, J. (2003). World Englishes: A resource book for students. London: Arnold.

[17] Jenkins, J. (2007). English as a lingua franca: Attitude and identity. Oxford: Oxford University Press.

[18] Kachru, B. B. (1985). Standards, codification and sociolinguistic realm: The English language in the outer circle. In R. Quirk \& H. G. Widdowson (Eds.), English in the world (pp. 11-18). Cambridge: Cambridge University Press.

[19] Kachru, Y., \& Smith, L. E. (2008). Cultures, contexts and world Englishes. New York: Routledge.

[20] Kirkpatrick, A. (2007). World Englishes: Implications for international communication and English language teaching. Cambridge: Cambridge University Press.

[21] Kosslyn, S. M. (2006). On the evolution of human motivation: The role of social prosthetic systems. In S. M. Platek, T. K. Shackelford \& J. P. Keenan (Eds.), Evolutionary cognitive neuroscience (pp. 541-554). Cambridge, MA: MIT Press.

[22] Larsen-Freeman, D. (2007). Reflecting on the cognitive-social debate in second language acquisition. Modern Language Journal, 91(5), 773-787.

[23] Lippi-Green, R. (1997). English with an accent: Language, ideology, and discrimination in the United States. London: Routledge.

[24] Mattock, J. (Ed.). (2003). Cross-cultural communication: The essential guide to international business (Revised 2 ed.). London: Kogan Page.

[25] McKay, S. L., \& Bokhorst-Heng, W. D. (2008). International English in its sociolinguistic contexts: Towards a socially sensitive EIL pedagogy. New York: Routledge.

[26] Milroy, J., \& Milroy, L. (1999). Authority in language: Investigating standard English (3 ed.). London: Routledge.

[27] Nihalani, P., Tongue, R. K., Hosali, P., \& Crowther, J. (Eds.). (2004). Indian and British English: A handbook of usage and pronunciation (2 ed.). New York: Oxford University Press.

[28] Pennycook, A. (1994). The cultural politics of English as an international language. London: Longman.

[29] Rickford, J. R. (1999). African American vernacular English: Features, evolutions, educational implications. Malden, Massachusetts: Blackwell Publishers Ltd.

[30] Sailaja, P. (2009). Indian English. Edinburgh: Edinburgh University Press.

[31] Scales, J., Wennerstrom, A., Richard, D., \& Wu, S.-H. (2006). Language learners' perceptions of accents. TESOL Quarterly, 
40(4), 715-738.

[32] Smith, L. E. (1992). Spread of English and issues of intelligibility. In B. B. Kachru (Ed.), The other tongue (pp. 76-90). Urbana. IL: University of Illinois Press.

[33] Trudgill, P. (2004). New-dialect formation: The inevitability of colonial Englishes. New York: Oxford University Press.

[34] Upton, C. (2008). Received pronunication. In B. Kortmann \& C. Upton (Eds.), Varieties of English 1: The British isles (pp. 237-252). Berlin: Mouton de Gruyter.

[35] Wajnryb, R. (2008). You know what I mean? : Words, contexts and communication. New York Cambridge University Press.

[36] Wassink, A. B. (1999). Historic Low Prestige and Seeds of Change: Attitudes toward Jamaican Creole. Language in Society, 28(1), 57-92.

[37] Wells, J. C. (1982). Accents of English. Cambridge: Cambridge University Press.

[38] Widdowson, H. G. (1994). The ownership of English. TESOL Quarterly, 28(2), 377-389.

[39] Wolf, H.-G. (2008). Cognitive linguistic approaches to world Englishes: An analysis of the community model in African English. Berlin: Mouton De Gruyter.

James H. Yang is Assistant Professor at National Yunlin University of Science and Technology, Taiwan. His research has recently focused on different English accents in attempt to construct the core English phonology for accommodating the needs of mutual intelligibility and national identities in the use of English as a lingua franca for international communication. 